\title{
Pengaruh Dosis Inokulum dan Lama Fermentasi Campuran Dedak Padi dan Darah dengan Bacillus amyloliquefaciens terhadap Kandungan Serat Kasar, Kecernaan Serat Kasar dan Energi Metabolisme
}

\section{The Effect of Innocullum Dosage and Fermentation Period of Mixtured Rice Bran and Blood Fermented by Bacillus amyloliquefaciens on Crude Fiber Content, Crude Fiber Digestibility, and Energy Metabolism}

\author{
Wizna $^{1}$, H. Muis ${ }^{1}$ A. Deswan ${ }^{2}$ \\ 1) Bagian Ilmu Nutrisi dan Teknologi Pakan, Fakultas Peternakan Universitas Andalas \\ ${ }^{2)}$ Program Studi Peternakan, Fakultas Peternakan Universitas Andalas \\ Kampus Unand Limau Manis, Padang 25163 \\ e-mail : wiznazhari57@yahoo.co.id \\ (Diterima: 16 Februari 2014; Disetujui: 24 Mei 2014)
}

\begin{abstract}
ABSTRAK
Suatu penelitian telah dilakukan untuk mengetahui pengaruh dosis inokulum dan lama fermentasi campuran dedak padi dan darah dengan Bacillus amyloliquefaciens terhadap kandungan serat kasar, kecernaan serat kasar dan energi metabolisme. Metode eksperimen dengan Rancangan Acak Lengkap (RAL) pola faktorial $2 \times 3$ digunakan dengan 3 ulangan. Faktor pertama, dosis inokulum yaitu A1:1\% dan A2:3\%. Faktor kedua, lama fermentasi B1:1 hari, B2:3 hari, B3:5 hari. Peubah yang diamati adalah kandungan serat kasar, kecernaan serat kasar, dan energi metabolisme. Hasil penelitian menunjukkan bahwa tidak terdapat interaksi antara dosis inokulum dan lama fermentasi campuran dedak padi dan darah pada kandungan serat kasar dan energi metabolisme. Pada kecernaan serat kasar terjadi interaksi terhadap dosis inokulum dan lama fermentasi dengan dosis inokulum dan lama fermentasi campuran dedak padi dan darah fermentasi. Lama fermentasi menunjukkan pengaruh yang berbeda nyata $(\mathrm{P}<0.05)$ terhadap kandungan serat kasar dan energi metabolisme. Kesimpulannya, kualitas gizi terbaik dari fermentasi campuran dedak padi dan darah dengan Bacillus amyloliquefaciens diperoleh pada dosis 3\% dan lama fermentasi 3 hari, dengan kandungan serat kasar 7,93 \%, kecernaan serat kasar 45,11\%, dan energi metabolisme 3195 kkal.
\end{abstract}

Kata kunci : dedak padi, darah, fermentasi, Bacillus amyloliquefaciens, kualitas produk

\begin{abstract}
An experiment was conducted to evaluate the effect of innocullum dosage and fermentation period of mixtured rice bran and blood fermented by Bacillus amyloliquefaciens on crude fiber content, crude fiber digestibility, and energy metabolism. The experiment used a factorial completely randomized design with 2 factors. The first factor was innocullum dosage (1 and 3\%), and the second factor was fermentation period (1, 2, and 3 days), and each treatment was replicated 3 times. Measured variables consisted of crude fiber content, crude fiber digestibility, and energy metabolism. The result showed that there was no integration between innocullum dosage and fermentation period on crude fiber content and energy metabolism of mixtured rice bran and blood, while crude fiber content and energy metabolism were affected by fermentation period $(P<0.05)$. Thus the best nutrient quality of mixtured rice brain and blood fermented by Bacillus amyloliquefaciens was $3 \%$ innocullum dosage and 3 days fermentation period with 7.93 $\%$ crude fiber content, $45.11 \%$ crude fiber digestibility and $3195 \mathrm{kka} / \mathrm{kg}$ energy metabolism.
\end{abstract}

Keywords : rice bran, blood, fermentation, Bacillus amyloliquefaciens, product 


\section{PENDAHULUAN}

Kendala peternakan unggas secara intensif adalah mahalnya harga pakan. Biaya pakan merupakan biaya tertinggi dibandingkan dengan biaya produksi lainnya. Murtidjo (1987) biaya pakan dalam usaha peternakan mencapai $60-70 \%$ dari seluruh biaya produksi. Untuk menekan biaya ini perlu dicari sumber bahan pakan lain yang harganya relatif murah, nilai gizinya tinggi serta tersedia dalam jumlah yang cukup besar, penggunaannya tidak bersaing dengan kebutuhan manusia dan mempunyai pengaruh yang baik terhadap ternak.

Dedak padi merupakan hasil sampingan dari proses pengolahan gabah yang cukup potensial digunakan sebagai bahan pakan unggas. Menurut BPS (2010) produksi gabah kering giling di Sumatera Barat tahun 2009 sebanyak 2.105.700 ton berpotensi memproduksi dedak kasar sebanyak 112.866 225.100 ton (8-16\% dari gabah kering giling) dan dedak halus $42.325-41.082$ ton atau 3$10 \%$ dari gabah kering giling. Menurut Utami (2011), Kandungan zat makanan dedak padi yakni BK sebesar 88,93\%, PK sebesar $12,39 \%$, SK sebesar $12,59 \%$, Ca sebesar $0,09 \%$ dan $\mathrm{P}$ sebesar $1,07 \%$. Kelemahan utama dedak padi sebagai pakan unggas adalah kandungan serat kasarnya yang cukup tinggi, protein rendah dan adanya senyawa fitat yang dapat mengikat mineral dan protein.

Darah merupakan hasil sampingan pemotongan ternak sapi atau kerbau yang dapat diolah menjadi tepung darah. Berdasarkan Laporan Ditjen Peternakan (2007) bahwa dari data jumlah pemotongan sapi dan kerbau tahun 2003-2007 di Sumatera Barat menunjukkan kenaikan jumlah pemotongan sapi sebesar $13,80 \%$ dan kerbau sebesar $4,35 \%$ per tahun. Frandson (1992), menyatakan bahwa jumlah darah dari seekor ternak kira-kira sampai $10 \%$ dari bobot badan dan juga tergantung dari spesies hewan dan status gizinya. Komposisi zat makanan darah segar yakni BK sebesar $20,2 \%$, protein $95,7 \%$, abu $4,1 \%$, lemak 0,2\%, Ca 0,89\%, P 0,25\% (Khalil dan Yuniza, 2011). Tepung darah mengandung $80-82 \%$ protein kasar dan sangat baik sebagai sumber asam amino lisin (kira-kira dua per tiga lisin dapat dimanfaatkan unggas). Kandungan ME tepung darah yaitu 2750 $\mathrm{kkal} / \mathrm{kg}$ (Scott et al., 1982). Protein tepung darah kurang dapat dimanfaatkan unggas karena didalam proses pembuatannya menggunakan suhu tinggi, sehingga asam amino leusin juga kurang dapat dimanfaatkan. Kandungan $\mathrm{Ca}$ dan $\mathrm{P}$ tepung darah juga lebih rendah dari pada tepung daging. Metode yang selama ini untuk membuat atau mengeringkan tepung darah yaitu pengeringan dengan pancaran sinar (flash drying) yang menghasilkan asam amino lisin cukup tinggi dan seragam (Rizal, 2006). Metode hasil flash drying memang baik untuk menghasilkan tepung darah yang berkualitas, akan tetapi membutuhkan biaya tinggi.

Kendala kualitas darah yang rendah dan sering mengalami kegagalan dalam pembuatan tepung darah, serta serat kasar yang cukup tinggi, protein kasar yang rendah dan adanya asam fitat pada dedak padi yang menyebabkan penggunaannya sebagai pakan ternak unggas terbatas. Untuk menutupi kekurangan masingmasing bahan tersebut, maka perlu diolah dengan mencampurkan keduanya, selanjutnya difermentasi dengan Bacillus amyloliquefaciens sebagai inolulum. Fermentasi dilakukan melalui metode penyerapan (Mann, 1980), dimana fungsi dedak yang dicampurkan dengan darah yaitu sebagai bahan pemadat dan pengikat, sehingga bentuk produk fermentasi akan menarik, disamping itu dedak akan dimanfaatkan oleh mikroorganisme sebagai sumber energi untuk pertumbuhan dan perkembangannya, sehingga mikroba cepat tumbuh dan mudah berkembang biak.

\section{METODE}

Bahan-bahan yang digunakan pada penelitian ini adalah inokulum Bacillus amyloliquefaciens, dedak padi, darah, media nutrient agar (NA), alkohol, aquades dan 21 ekor ayam broiler umur 6 minggu.

Penelitian ini menggunakan rancangan acak lengkap (RAL) pola faktorial $2 \times 3$ dengan 3 ulangan. Perlakuan faktor A adalah 2 level 
dosis inokulum (1\%, 3\%), dan faktor B adalah 3 level lama fermentasi (1 hari, 3 hari, 5 hari).

Parameter yang diukur adalah Kandungan serat kasar (metode AOAC, 1990). Prinsip serat kasar adalah semua senyawa organik yang tak larut dalam perebusan menggunakan larutan $\mathrm{H}_{2} \mathrm{SO}_{4}$ dan $\mathrm{NaOH}$. Penentuan Kecernaan serat kasar (Sibbald, 1975), daya cerna serat kasar dapat diketahui dengan cara mengurangi jumlah serat kasar dikonsumsi dengan serat kasar yang terdapat pada fesesnya. Penentuan energi metabolisme (Sibbald, 1975).

Data penelitian yang diperoleh diolah secara statistik dengan menggunakan analisis ragam menurut Rancangan Acak Lengkap (RAL) pola faktorial. Perbedaan antar perlakuan diuji dengan Duncan's Multiple Range Test (DMRT).

\section{HASIL DAN PEMBAHASAN}

\section{Pengaruh Perlakuan Terhadap Kandungan Serat Kasar}

Rataan kandungan serat kasar dari campuran dedak padi dan darah fermentasi (CDPDF) dengan Bacillus amyloliquefaciens untuk masing- masing perlakuan dapat dilihat pada Tabel 1.

Dari Tabel 1 dapat dilihat rataan persentase kandungan serat kasar dari CDPDF dengan Bacillus amyloliquefaciens yang tertinggi pada $\mathrm{A}_{1} \mathrm{~B}_{1}$ sebesar $9,39 \%$, diikuti oleh $\mathrm{A}_{2} \mathrm{~B}_{1}$ sebesar $8,88 \%$ dan yang terendah pada $\mathrm{A}_{2} \mathrm{~B}_{3}$ sebesar $7,17 \%$. Hasil analisis ragam menunjukkan bahwa tidak terdapat interaksi $(\mathrm{P}>0.05)$ antara dosis inokulum dan lama fermentasi terhadap kandungan serat kasar, begitu juga faktor dosis inokulum memberikan pengaruh yang berbeda tidak nyata $(\mathrm{P}>0.05)$, akan tetapi lama fermentasi memberikan pengaruh yang berbeda nyata $(\mathrm{P}<0,05)$, terhadap kandungan serat kasar campuran dedak padi dan darah fermentasi.

Hasil uji DMRT terhadap lama fermentasi, menunjukkan bahwa kandungan serat kasar pada perlakuan $\mathrm{B}_{1}$ berbeda nyata $(\mathrm{P}<0,05)$ lebih tinggi dari pada perlakuan $\mathrm{B}_{3}$, namun perlakuan $B_{1}$ berbeda tidak nyata $(\mathrm{P}>0,05)$ dibandingkan kandungan serat kasar pada perlakuan $B_{2}$, begitu juga perlakuan $B_{2}$ berbeda tidak nyata $(\mathrm{P}>0,05)$ dibandingkan dengan kandungan serat kasar pada perlakuan $\mathrm{B}_{3}$. Hal ini disebabkan pada perlakuan $\mathrm{B}_{3}$, waktu fermentasi lebih lama dari $\mathrm{B}_{1}$ dan $\mathrm{B}_{2}$, sehingga kesempatan enzim untuk merombak serat kasar terutama selulosa dan hemiselulosa menjadi lebih sempurna, selanjutnya pada perlakuan $\mathrm{B}_{3}$ proses fermentasi menunjukkan produk berbau khas frermentasi yaitu berbau asam dengan $\mathrm{pH}$ 4,72. Bakteri Bacillus amyloliquefaciens bersifat selulolitik dan dapat mendegradasi serat kasar karena menghasilkan enzim ekstrakseluler selulase dan hemiselulase, sehingga kandungan serat kasar dari CDPDF menjadi turun. Menurut Winarno (1980) pengaruh fermentasi terhadap serat kasar adalah terjadinya pemecahan zat-zat kompleks yang terdapat pada substrat oleh enzim mikroba seperti perombakan selulosa, hemiselulosa dan polimer-polimernya sehingga akan dihasilkan gula sederhana dan turunan serat kasar.

\section{Pengaruh Perlakuan Terhadap Kecernaan Serat Kasar}

Dari Tabel 2 dapat dilihat rataan persentase kecernaan serat kasar dari CDPDF dengan Bacillus amyloliquefaciens yang tertinggi pada A1B2 sebesar 47,78\%, diikuti

Tabel 1. Rataan kandungan serat kasar dari CDPDF dengan Bacillus amyloliquefaciens pada masing-masing perlakuan (\%)

\begin{tabular}{lcccc}
\hline \multirow{2}{*}{ Faktor A } & \multicolumn{3}{c}{ Faktor B } & \multirow{2}{*}{ Rata-rata } \\
\cline { 2 - 4 } & B1 (1 hari) & B2 (3 hari) & B3 (5 hari) & \\
\hline A1 (1\%) & 9,39 & 8,24 & 7,88 & 8,50 \\
A2 (3\%) & 8,88 & 7,93 & 7,17 & 7,99 \\
\hline Rata-rata & $9,13^{\mathrm{a}}$ & $8,08^{\mathrm{b}}$ & $7.52^{\mathrm{b}}$ & \\
\hline
\end{tabular}

Keterangan : Superskrip huruf kecil yang berbeda menunjukkan berbeda nyata $(\mathrm{P}<0,05)$ 
Tabel 2. Rataan kecernaan serat kasar ayam broiler masing-masing perlakuan selama penelitian $(\%)$

\begin{tabular}{lcccc}
\hline \multirow{2}{*}{ Faktor A } & \multicolumn{3}{c}{ Faktor B } & \multirow{2}{*}{ Rata-Rata } \\
\cline { 2 - 4 } & B1 (1 hari) & B2 (3 hari) & B3 (5 hari) & \\
\hline A1 (1\%) & $45,62^{\mathrm{a}}$ & $47,78^{\mathrm{a}}$ & $37,41^{\mathrm{b}}$ & 43,60 \\
A2 (3\%) & $47,64^{\mathrm{a}}$ & $45,11^{\mathrm{a}}$ & $47,58^{\mathrm{a}}$ & 46,78 \\
\hline Rata-Rata & 46,63 & 46,45 & 42,50 & \\
\hline
\end{tabular}

Keterangan : Superskrip huruf kecil yang berbeda menunjukkan berbeda nyata $(\mathrm{P}<0,05)$

oleh A2B1 sebesar $47,64 \%$ dan yang terendah pada A1B3 sebesar $37,41 \%$. Hasil analisis keragaman menunjukkan bahwa pengaruh perlakuan pada faktor A (dosis) dan faktor B (lama fermentasi) berbeda tidak nyata $(\mathrm{P}>0,05)$ terhadap kecernaan serat kasar. Terdapat interaksi pada faktor $\mathrm{AB}$ (dosis dan lama) berbeda nyata $(\mathrm{P}<0,05)$.

Hasil uji lanjut DMRT kombinasi perlakuan dosis inokulum dan lama fermentasi diperoleh kecernaan serat kasar CDPDF dengan bakteri Bacillus amyloliquefaciens tertinggi pada kombinasi suplementasi A1B2 (dosis 1\%, lama 3 hari) memberikan kecernaan serat kasar yang paling baik. Tingginya kecernaan serat kasar pada perlakuan A1B2 erat kaitannya dengan pertumbuhan mikroba dan komponen dari beberapa enzim. Dengan longgarnya ikatan lignoselulosa akan memudahkan penetrasi enzim yang dihasilkan mikroba (Jackson, 1977 dalam Hanafi, 2004).

Tingginya daya cerna serat kasar pada CDPDF karena Bacillus amyloliquefaciens juga berfungsi sebagai probiotik pada unggas yang mengkonsumsinya. Dengan adanya spora bakteri Bacillus amyloliquefaciens pada produk fermentasi dan berkembang di usus halus dan menghasilkan enzim selulosa yang memecah serat kasar, sehingga kecernaan dan penyerapan lebih banyak pada usus halus. Bacillus amyloiquefaciens ini dapat hidup di usus halus ayam karena bakteri tersebut dapat tumbuh baik di bawah kondisi aerobik sampai anaerobik fakultatif, menghasilkan spora tahan panas, mampu tumbuh pada suhu $8-60{ }^{\circ} \mathrm{C}, \mathrm{pH}$ 2-8 dan pada larutan garam konsentrasi tinggi yaitu 10\% (Wizna et al., 2005). Faktor yang mempengaruhi pencernaan dan penyerapan serat kasar adalah bentuk dan jenis serat kasar itu sendiri. Seperti dijelaskan oleh Anggorodi (1994) bahwa dalam proses pencernaan serat kasar dengan pertolongan bakteri, maka hasil utama yang dapat digunakan adalah asamasam organik sebagian besar asam asetat, asam-asam organik kemudian diserap dan digunakan dalam tubuh sama halnya dengan glukosa.

Terjadi penurunan daya cerna serat kasar pada perlakuan A1B3 disebabkan kurang maksimalnya aktifitas enzim merombak serat kasar pada substrat, diperkirakan serat kasar pada substrat tersebut merupakan komponen yang sulit dicerna seperti lignin dan silica.

\section{Pengaruh Perlakuan terhadap Energi Metabolisme}

Rataan energi metabolisme dari CDPDF dengan Bacillus amyloliquefaciens yang tertinggi pada A1B3 sebesar 3402 kkal, diikuti oleh A2B3 sebesar $3373 \mathrm{kkal}$ dan yang terendah pada A1B1 sebesar $2990 \mathrm{kkal}$ (Tabel 3). Untuk melihat pengaruh dosis inokulum dan lama fermentasi pada CDPDF terhadap

Tabel 3. Rataan Energi Metabolisme Ayam Broiler Masing-masing Perlakuan Selama Penelitian (kkal)

\begin{tabular}{lcccc}
\hline \multirow{2}{*}{ FAKTOR A } & \multicolumn{3}{c}{ FAKTOR B } & \multirow{2}{*}{ Rata-Rata } \\
\cline { 2 - 4 } & B1 (1 hari) & B2 (3 hari) & B3 (5 hari) & \\
\hline A1 $(1 \%)$ & 2990 & 3125 & 3402 & 3173 \\
A2 $(3 \%)$ & 3074 & 3195 & 3373 & 3214 \\
\hline Rata-Rata & $3032^{\mathrm{b}}$ & $3160^{\mathrm{b}}$ & $3388^{\mathrm{a}}$ \\
\hline
\end{tabular}

Keterangan: Superskrip huruf kecil yang berbeda menunjukkan berbeda nyata $(\mathrm{P}<0,05)$ 
kandungan serat kasar dilakukan analisis ragam. Dari hasil analisis keragaman menunjukkan bahwa pengaruh perlakuan pada faktor A (dosis) berbeda tidak nyata $(\mathrm{P}>0,05)$ sedangkan pada faktor B (lama) berbeda sangat nyata $(\mathrm{P}<0,01)$ terhadap energi metabolisme. Tidak terdapat interaksi pada faktor $\mathrm{AB}$ (dosis dan lama) berbeda tidak nyata $(\mathrm{P}>0,05)$.

Hasil uji DMRT terhadap lama fermentasi menunjukkan bahwa energi metabolime pada perlakuan $\mathrm{B} 3$ berbeda nyata $(\mathrm{P}<0,05)$ lebih tinggi dari pada perlakuan $\mathrm{B} 1$ dan perlakuan $\mathrm{B} 2$, namun perlakuan $\mathrm{B} 2$ berbeda tidak nyata $(\mathrm{P}>0.05)$ dibandingkan energi metabolime pada perlakuan B1. Semakin baik pertumbuhan bakteri maka semakin banyak pula enzim selulase yang dihasilkan untuk merombak karbohidrat dan serat kasar menjadi glukosa yang akhirnya meningkatkan nilai energi metabolisme yang dimanfaatkan oleh ternak. Hal ini sesuai dengan pendapat Winarno (1980) yang menyatakan bahwa produk yang mengalami fermentasi memiliki kualitas yang lebih baik dan lebih mudah dicerna oleh ternak.

\section{KESIMPULAN}

Berdasarkan hasil penelitian dapat disimpulkan bahwa fermentasi campuran dedak padi dan darah fermentasi dengan Bacillus amyloliquefaciens yang terbaik pada dosis $3 \%$ selama 3 hari dan dapat menurunkan kandungan serat kasar dari 11,27\% menjadi $7,93 \%$ dengan persentase penurunan sebesar $29.64 \%$, meningkatkan kecernaan serat kasar dari $36,42 \%$ menjadi $45,11 \%$ dengan persentase peningkatan sebesar $19,26 \%$ dan meningkatkan energi metabolisme dari $2956 \mathrm{kkal}$ menjadi $3195 \mathrm{kkal}$ dengan persentase peningkatan sebesar 7,48\%.

\section{DAFTAR PUSTAKA}

Buckle, K. A., R. A. Edward, C. H. Fleed and M. Wooton. Diterjemahkan oleh Adino dan Purnomo. 1987. Ilmu Pangan. UI Press, Jakarta.

Dilahari, W. 2010. Pengaruh kombinasi ransum komersil (CP 511) dengan dedak padi terhadap peforma ayam broiler yang diberi probiotik Bacillus amyloliquefaciens. Skripsi. Fakultas Peternakan Universitas Andalas, Padang.

Donkoh, A., C.C. Atuahene., D.M. Anang and S.K. Ofori. 1999. Chemical composition of solar-dried blood meal and its effect on performance of broiler chickens. Animal Feed Science and Technology 81: 299 - 307.

Fardiaz, S. 1992. Teknologi Fermentasi. Jurusan Teknologi Pangan dan Gizi, Fakultas Pertanian, IPB. Bogor.

Garbutt, J. 1997. Essentiales of Food Microbiology. Formerly Senior Lecturer in Microbiology Humberside University. UK.

Hermon, dan A. Djulardi. 1999. Proses limbah darah rumah potong hewan (RPH) sebagai sumber protein pakan ternak. Penelitian Vucer Proyek Pengembangan Pusat Studi Lingkungan. Ditjen Dikti. Departemen Pendidikan dan Kebudayaan. Padang.

Irving, G. C. J. 1980. In Inositol Phosphatase : Their Chemistry, Biochemistry and Physiology. Ed., Cosgrove, D. J. Elsevier, Amsterdam.

Khalil dan Yuniza A. 2011. Pengetahuan Bahan Pakan. Fakultas Peternakan Universitas Andalas. Padang.

Koumoutsi, A., X. Chen, A. Henne, H. Liesegang, G. Hitzeroth, P. Franke, J. Vater and R. Borriss. 2004. Scanning electron micrograph of a pea root with adhering B. amyloliquefaciens cells. Bacteriology. pp. 1084-1096, vol. 186,No. 4.

Koumoutsi, A., X. Chen, A. Henne, H. Liesegang, G. Hitzeroth, P. Franke, J. Vater and R. Luizmeira. Com/enzimas.htm. USD Recomendar esta Pagina. 2005.

Lind, T., Bo Lonnerda, Lars-Ake persson , $\mathrm{H}$. Stenlund C. Tennefors \& O. Hernell. 
2003. Effects of weaning cereals with different phytate contents on hemoglobin, iron stores, and serum zinc: a randomized intervention in infants from 6 to 12 mo of age. Am. J. Clin. Nutr. 78: 168-175.

Luizmeira.Com/enzimas.htm. 2005. USB Recomendar esta pagina.

Mann, I. 1980. Meat and Carcass by Products. In An Introduction to Animal Husbandry in Tropics. Ed by logman Inc. New York.

Meliafitri. 2006. pengaruh pemberian produk onggok fermentasi dengan Bacillus amyloliquefaciens dalam ransum terhadap bobot hidup, persentase karkas dan income over feed cost ayam broiler. Skripsi. Fakultas Peternakan Unand, Padang.

Moeljoharjo, D. S. 1979. Pengantar Biokimia. Departemen Biokimia Fakultas Kedokteran Hewan. IPB. Bogor.

Priest, F. G., M. Goodfelow, L. A. Shute and R. C. W. Berkeley. 1987. B. Amyloliquefaciens sp. Nov., nom. Rev. Int. J. Syst. Bacteriol., 37 : 69-71.

Saono, S. 1976. Pemanfaatan jasad renik dalam pengolahan hasil sampingan atau sisa-sisa hasil produksi pertanian. Berita LIPI. 18(4) : 1-11. Jakarta.

Said, E.G. 1985. Pengantar Bioindustri. Agroindustri Press. Jurusan TIN Fapeta, IPB.

Scott, M.L., M.C. Neisheim and R.J Young. 1982. Nutrion of The Chicken. Third Ed. M.L. Scott and Associates, Ithaca, New York.

Siagian, P.H. 1994. Pemanfaatan limbah Rumah Pemotongan Hewan (RPH), Upaya pengelolaan ekosistem pertanian dan usaha peternakan;materi pelatihan inspektur/pengawas pengelolaan lingkungan. Cipayung, 12-17 Desember 1994.
Sibbald, I. R. 1976. The effect of level of feed intake on metabolizem energy value. Adult of Roasters. Journal Poultry. Sci 54: 130-14.

Steel, R. G. D and J. H. Torrie. 1991. Prinsip dan Prosedur Statistik Suatu Pendekatan Biometrik. PT. Gramedia Pustaka Utama, Jakarta.

Sukara, E. dan Atmowidjojo. 1980. Pemanfaatan ubi kayu untuk produksi enzim amilase dan PST dengan menggunakan kapang Rhyzophus oligosporus. Seminar Nasional UPT-EPG, Lampung.

Sumiati, 2005. Rasio molar asam fitat: $\mathrm{Zn}$ untuk menentukan suplementasi $\mathrm{Zn}$ dan enzim phytase dalam ransum berkadar asam phytat tinggi. Disertasi. Sekolah

Utami, Y. 2011. Pengaruh Imbangan Feed Suplemen Terhadap Kandungan Protein Kasar, Kalsium Dan Fosfor Dedak Padi Yang Difermentasi Dengan Bacillus amyloliquefaciens. Skripsi. Fakultas Peternakan Universitas Andalas, Padang.

Wizna, H. Abbas, Y. Rizal, A. Dharma dan I. P. Kompiang. 2005. Potensi Bacillus amyloliquefaciendari serasah hutan sebagai probiotikayam broiler. Dalam: Prosiding Seminar Nasional dan Rapat Tahunan Dekan-dekan Bidang Ilmu Pertanian BKS-PTN Wilayah Barat, Padang.

Wizna. 2006. Potensi Bacillus amyloliquefaciens isolat serasah hutan dalam peningkatan kualitas pakan campuran empelur sagu dan isi rumen dan implikasinya terhadap produktivitas ternak unggas. Disertasi Pascasarjana Universitas Andalas. Padang.

Wizna, H. Abbas, Y. Rizal, A. Dharma dan I. P. Kompiang. 2007. Selection and identification of cellulase-producing bacteria isolated from the litter of mountain and swampy forest. Microbiology Indonesia Journal, December 2007, P 135-139 Volume 1, Number 3 ISSN 1978-3477. 